\title{
Respon Histomorfometrik Aorta Tikus Putih terhadap Pemberian Berbagai Kadar Vco dan Olive Oil
}

\section{White Rat Aorta Histomorfometrik Response to Giving Various Levels of VCO and Olive Oil}

\author{
Enny Yusuf Wachidah Yuniwarti*, Muhammad Anwar Djaelani \\ Departemen Biologi, Fakultas Sains dan Matematika, Universitas Diponegoro \\ Jl. Prof. Soedarto, SH, Tembalang, Semarang \\ *Email: enny_yusuf@yahoo.co.id
}

Diterima 20 Juni 2016 / Disetujui 19 Agustus 2016

\begin{abstract}
ABSTRAK
Penelitian ini bertujuan untuk mengkaji efek asam lemak jenuh yang menggunakan VCO dan efek asam lemak tak jenuh yang menggunakan olive oil terhadap histomorfometrik aorta tikus putih yang diamati melalui pengukuran ketebalan tunika intima. Penelitian ini menggunakan tikus putih sebanyak 25 ekor yang dibagi dalam lima perlakuan, yaitu P1 adalah kelompok kontrol, P2 merupakan kelompok yang diberi Olive Oil $10 \mathrm{~mL} / \mathrm{kg}$ pakan, $\mathrm{P} 3$ merupakan kelompok yang diberi Olive Oil $5 \mathrm{~mL} / \mathrm{kg}$ pakan, P4 merupakan kelompok yang diberi VCO $10 \mathrm{~mL} / \mathrm{kg}$ pakan dan P5 merupakan kelompok yang diberi VCO $5 \mathrm{~mL} / \mathrm{kg}$ pakan. Tiap perlakuan diulang sebanyak 5 kali ulangan. Data tebal tunika intima yang didapat, dianalisis menggunakan analisis of varians (ANOVA) dengan design penelitian menggunakan rancangan acak lengkap dengan lima perlakuan dan lima ulangan. Hasil yang didapat menunjukkan tidak terdapat beda nyata antar perlakuan, sehingga dapat disimpulkan bahwa pemberian olive oil maupun virgin coconut oil tidak menimbulkan perbedaan respon histomorfometrik aorta tikus putih.
\end{abstract}

Kata kunci: tikus putih, tunika intima, olive oil, vco

\begin{abstract}
This research aimed to determine differences of intimal thickening after feeding saturated fatty acid and unsaturated fatty acid. Elevated level of fatty acid may contribute to damage of intimal thickening use histomorphometric analysis of aorta. This research used 25 white rat. The method applied was Completely Randomized Design in which the factor was five levels of VCO and Olive Oil namely P1, P2, P3, P4 and P5. $\mathrm{P} 1$ was the control group, $\mathrm{P} 2$ was a group with $10 \mathrm{~mL}$ Olive Oil $/ \mathrm{kg}$ feed. P3 was a group with $5 \mathrm{~mL}$ Olive Oil $/ \mathrm{kg}$ feed. P4 was a group with $10 \mathrm{~mL} \mathrm{VCO} / \mathrm{kg}$ feed. P5 was a group with $5 \mathrm{~mL} \mathrm{VCO} / \mathrm{kg}$ feed. Each group repeated five times. Feed and water were given ad libitum for four weeks. The result showed that there was no significant of intimal thickening between treatments.
\end{abstract}

Keywords: albino rat, tunica intima, VCO, Olive Oil

\section{PENDAHULUAN}

Aorta merupakan pembuluh darah yang terdiri atas tiga lapisan, yang paling dalam adalah tunika intima atau tunika interna terdiri atas selapis sel endotel yang membatasi permukaan dalam pembuluh. Otot polos dan jaringan ikat jarang halus terdapat di bagian sub endotel. Lapisan berikutnya adalah tunika media yang tersusun atas otot polos melingkar, diantara otot polos terdapat kolagen, elastin dan proteoglikan. Tunika adventitia dipisahkan dengan tunika media melalui membran elastika tipis, terdiri atas serabut elastin dan kolagen (Komolafe et al., 2013). Metode analisis histomorfometrik aorta dapat digambarkan 
melalui ketebalan tunika intima (Ageraek et al., 1999).

Asam lemak jenuh merupakan bagian terbesar yang terkandung dalam Virgin Coconut Oil (VCO), selain itu juga kaya akan antioksidan serta mampu menurunkan kadar trigliserid dan kolesterol. Komponen unsaponifiable seperti vitamin $\mathrm{E}$ dan polyphenol yang terdapat di dalam VCO mampu meningkatkan enzim-enzim antioksidan dan menurunkan kandungan peroksida (Lu dan Tan, 2009). Beberapa penelitian menunjukkan bahwa VCO mampu meningkatkan aktivitas fagositosis makrofag pada ayam yang diinfeksi virus avian influenza (Yuniwarti et al., 2013). Virgin coconut oil mampu meningkatkan antioksidan (Nevin dan Rajamohan 2006), juga menimbulkan efek antithrombotic (Nevin dan Rajamohan, 2007)..

Asam oleat merupakan asam lemak tak jenuh dan terdapat paling banyak pada Olive oil sehingga termasuk dalam kelompok MUFA atau mono unsaturated fatty acid. Kandungan olive oil yang terdiri atas asam lemak dan vitamin menyebabkan olive oil berperan pada proses mineralisasi dan perkembangan tulang, serta berperan sebagai antioksidan karena adanya oleocanthal dan oleuropein yang serupa dengan vitamin E (Saleh dan Hanan, 2011). Olive oil juga mengandung komponen fenol yang mempunyai efek positif terhadap beberapa parameter fisiologis seperti lipoprotein plasma, kerusakan oksidatif, inflamasi serta aktivitas antimikrobial (Cicerale et al., 2010).

Diet lemak yang mengandung asam lemak jenuh dan asam lemak tak jenuh diperkirakan mempunyai dampak yang berbeda karena perbedaan absorpsi asam lemak tersebut akan mempengaruhi oksidasi, pembentukan energi dan pembentukan lemak total ( $\mathrm{Su}$ and Jones, 1993). Triasilgliserol atau trigliserida merupakan lemak yang paling banyak terdapat dalam tubuh (Skeaff dan Mann, 2014). Peningkatan trigliserid merupakan penanda bagi terjadinya kondisi sakit atau kelainan metabolisme, maka peningkatan trigliserid yang terjadi dapat menyebabkan pankreatitis ( Brown et al., 2012). Infeksi pankreas dapat memicu terjadinya aterosklerosis. Proses infeksi dapat menyebabkan terjadinya aterosklerosis melalui inflamasi yang melibatkan pembuluh darah. Aterosklerosis merupakan penebalan dinding arteri atau aorta yang membentuk lesi. Lesi tersebut berupa lemak yang dilapisi jaringan fibrosa, yang dapat mengganggu aliran darah yang selanjutnya dapat menyebabkan kematian jaringan (Permana et al., 2013).

Berdasarkan hal tersebut maka perlu untuk diteliti lebih lanjut mengenai efek asam lemak jenuh yang menggunakan VCO dan efek asam lemak tak jenuh yang menggunakan olive oil terhadap histomorfometrik aorta tikus putih.

\section{METODE PENELITIAN}

Penelitian tentang efek asam lemak jenuh dan asam lemak tak jenuh terhadap berbagai parameter fisiologis dilakukan di laboratorium Struktur dan Fungsi Hewan, Departemen Biologi, FSM-UNDIP. Penelitian ini menggunakan tikus putih jantan sebanyak 25 ekor yang dibagi dalam 5 kelompok perlakuan yaitu P1 adalah kelompok kontrol, P2 merupakan kelompok yang diberi Olive Oil $10 \mathrm{~mL} / \mathrm{kg}$ pakan, P3 merupakan kelompok yang diberi Olive Oil $5 \mathrm{~mL} / \mathrm{kg}$ pakan, P4 merupakan kelompok yang diberi VCO 10 $\mathrm{mL} / \mathrm{kg}$ pakan dan P5 merupakan kelompok yang diberi VCO $5 \mathrm{~mL} / \mathrm{kg}$ pakan. Tiap perlakuan diulang sebanyak 5 kali ulangan. Perlakuan selama 4 minggu. Data tebal tunika intima yang didapat dari pengamatan preparat mikroanatomi aorta melalui mikroskop yang dilengkapi kamera dan dihubungkan dengan komputer. Analisis data menggunakan analisis of varians (ANOVA) dengan rancangan penelitian menggunakan rancangan acak lengkap dengan lima perlakuan dan lima ulangan.

\section{HASIL DAN PEMBAHASAN}

Berdasarkan hasil analisis data menunjukkan bahwa tebal tunika intima aorta tikus putih kontrol maupun perlakuan, baik yang 
menggunakan VCO maupun olive oil pada dosis 5 dan $10 \mathrm{~mL} / \mathrm{kg}$ pakan berbeda tidak nyata. Hasil analisis tebal tunika intima tersebut dapat dilihat pada Gambar 1.

Perlakuan vco dan olive oil tidak menunjukkan adanya tebal tunika intima yang berbeda antar perlakuan maupun kontrol, yang diamati melalui preparat mikroanatomi aorta tikus putih sebagaimana tampak pada Gambar 2. Tebal tunika intima yang tidak berbeda nyata tersebut diduga karena VCO meskipun merupakan asam lemak jenuh namun mempunyai kandungan terbesar asam laurat yang merupakan rantai medium dengan panjang $\mathrm{C} 12$. Telah terjadi sugesti di masyarakat bila mengkonsumsi asam lemak jenuh maka akan meningkatkan kolesterol dalam darah. Komponen terbesar VCO adalah asam lemak jenuh yang mempunyai rantai medium. Medium chain fatty acid ini akan lebih mudah diabsorpsi dan selanjutnya akan lebih cepat menghasilkan energi dan bukan lemak. Tidak terbentuknya lemak tubuh secara berlebihan pada pemberian vco menyebabkan perlakuan dengan vco tidak menunjukkan terjadinya perbedaan perlemakan pada aorta yang dapat diamati melalui tebal tunika intima yang tidak berbeda nyata baik dengan kontrol maupun dengan perlakuan olive oil (Marina et al., 2000).

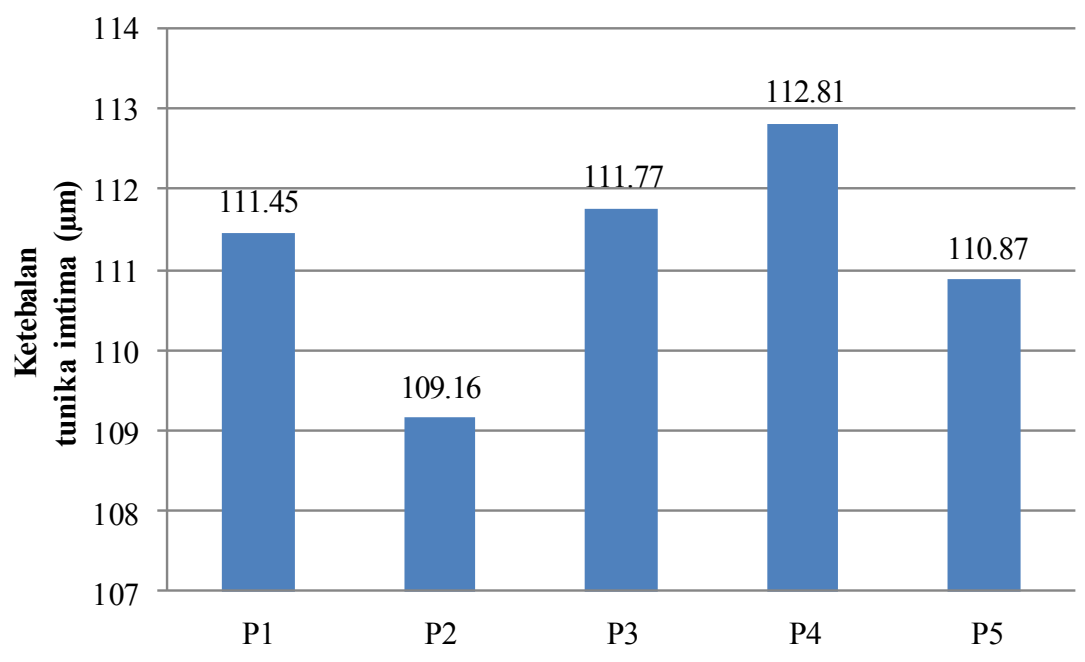

Gambar 1. Tebal Tunika Intima Aorta Tikus Putih pada Akhir Perlakuan

Keterangan :

P1: kelompok kontrol, P2 kelompok yang diberi Olive Oil $10 \mathrm{~mL} / \mathrm{kg}$ pakan, P3 kelompok yang diberi Olive Oil $5 \mathrm{~mL} / \mathrm{kg}$ pakan, $\mathrm{P} 4$ kelompok yang diberi VCO $10 \mathrm{~mL} / \mathrm{kg}$ pakan dan P5 kelompok yang diberi VCO $5 \mathrm{~mL} / \mathrm{kg}$ pakan.

Digesti asam lemak jenuh memerlukan garam empedu untuk emulsifikasi dan lipase pankreas untuk digesti tetapi molekul medium chain trigliserid dari coconut oil sangat mudah untuk diabsorpsi sehingga tidak memerlukan garam bilus maupun enzime lipase. Asam lemak bebas yang telah didigesti dan monogliserid akan langsung masuk ke dalam sel mukosa intestinum dan selanjutnya masuk ke dalam mitokondria hepar (Liau et al., 2011). Oksidasi asam lemak jenuh melalui rangkaian yang lebih pendek dibanding asam lemak tak jenuh. Urutan proses oksidasi asam lemak jenuh diawali dengan oksidasi Asil KoA, asam lemak jenuh diaktifkan terlebih dahulu dengan bantuan enzim Asil KoA dehidrogenase yang terdapat di dalam membran mitokondria. Enzim dehidrogenase akan membebaskan 2 atom hidrogen dari gugus asil untuk membentuk gugus enoil dalam bentuk isomer trans. Asil KoA dehidrogenase tidak mengandung $\mathrm{Fe}$ dan memindahkan elektron ke ubiquinon lewat suatu jalur yang diawali oleh suatu flavoprotein yang disebut flavoprotein pemindah elektron, diikuti oleh flavoprotein lain yang membentuk kompleks dengan Fe-sulfida (McGilvery dan Goldstein, 1996). 


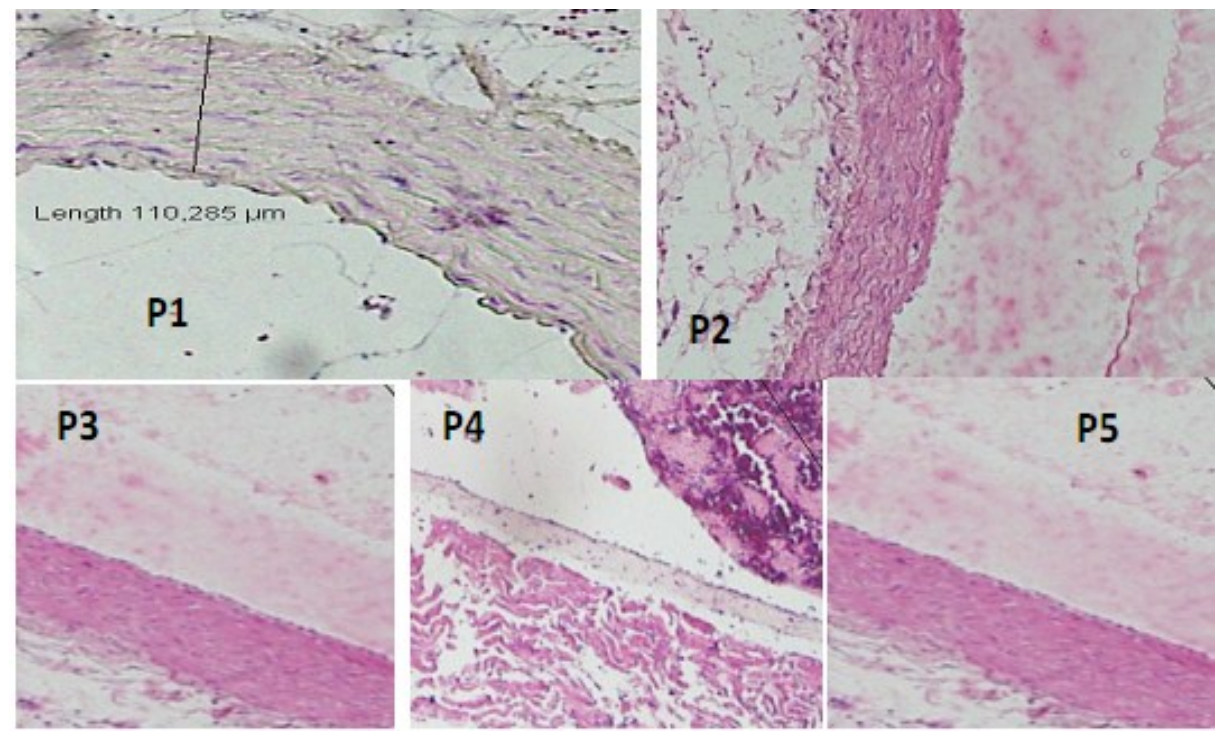

Gambar 2. Preparat Histologi Aorta Tikus Putih dengan Pewarnaan HE dan Perbesaran 100 X

Keterangan :

Tunika intima aorta tikus putih pada semua perlakuan tampak mempunyai tebal tunika intima yang tidak berbeda nyata. Tidak tampak adanya akumulasi lipid intrasel, maupun plak ateroma pada semua perlakuan. P1: kelompok kontrol, P2 kelompok yang diberi Olive Oil $10 \mathrm{~mL} / \mathrm{kg}$ pakan, P3 kelompok yang diberi Olive Oil $5 \mathrm{~mL} / \mathrm{kg}$ pakan, P4 kelompok yang diberi VCO $10 \mathrm{~mL} / \mathrm{kg}$ pakan dan P5 kelompok yang diberi VCO $5 \mathrm{~mL} / \mathrm{kg}$ pakan.

Olive oil merupakan mono unsaturated fatty acid (MUFA) yang mengandung komponen phenol terutama hydroxytyrosol, tyrosol, dan oleuropein. Olive oil juga mempunyai kandungan antioksidan yang besar dan adanya antioksidan tersebut melindungi hilangnya phenol. Konsumsi olive oil akan meningkatkan HDL, menurunkan LDL dan trigliserid, juga mempunyai efek proteksi terhadap kerusakan DNA (Cicerale et al., 2010). Infeksi diyakini sebagai stimulus inflamasi penting yang menyebabkan aterosklerosis. Proses inflamasi dapat terjadi secara langsung atau tidak langsung melibatkan pembuluh darah melalui hemostatik dan pemicu inflamasi sistemik (Permana et al., 2013). Kandungan fenol pada Olive Oil dan VCO merupakan antioksidan yang akan menghambat kerusakan sel endotel pada tunika intima sehingga dapat dicegah terjadinya aterosklerosis (Kogilavani et al., 2015).

Konsumsi VCO akan menurunkan komponen lipid yang membahayakan kesehatan seperti menurunkan kolesterol total, trigliserid, phospholipid, LDL, VLDL dan meningkatkan konsentrasi HDL. Penelitian lain menunjukkan bahwa VCO mengandung komponen unsaponifiable seperti vitamin E dan polyphenol sehingga konsumsi VCO dapat meningkatkan level enzim antioksidan dan menurunkan kandungan peroksida lemak. Kandungan asam lemak jenuh pada VCO akan membuat anti oksidan yang tinggi pada VCO menjadi stabil (Lu dan Tan, 2009). Berdasarkan kandungan fenol yang tinggi pada Olive Oil dan VCO yang mampu menghambat aterosklerosis maka pemberian VCO dan Olive oil tidak menyebabkan terjadinya aterosklerosis yang dapat diamati melalui tebal tunika intima pada aorta tikus putih yang tidak berbeda nyata.

\section{SIMPULAN}

Pengamatan histomorfometrik aorta tikus putih tidak memberikan respon yang berbeda terhadap pemberian berbagai kadar Virgin coconut oil dan Olive oil. 


\section{DAFTAR PUSTAKA}

Ageraek M., Ingrid B Kristensen, and Erik B Pedersen. 1999. A Histomorphometric Method For Evaluating Topographic Differences In Degree Of Early Atherosclerosis Within The Human Aorta. APMIS DOI: $\quad 10.1111 / \mathrm{j} .1699$ 0463.1999.tb01484.x Vol. 107, Issue 712March 1999 Pp 863-868.

Brown W. V., , J. D. Brunzell, R H. Eckel, N J. Stone,. 2012. Severe hypertriglyceridemia. Journal of Clinical Lipidology (2012) 6, 397-408.

Cicerale S., Lucas L. and R. Keas. 2010. Biological Activities of Phenolic Compounds Present in Virgin Olive Oil. Int. J. Mol. Sci. 2010, 11, 458-479; doi:10.3390/ijms11020458

Kogilavani Subermaniam, Qodriyah Haji Mohd Saad, Yusof Kamisah, and Faizah Othman. 2015. Effects of Virgin Coconut Oil on the Histomorphometric Parameters in the Aortae and Hearts of Rats Fed with Repeatedly Heated Palm Oil. International Journal of Bioscience, Biochemistry and Bioinformatics Vol 5, Number 2, March 2015 doi:10.17706/ijbbb.2015.v5. 120131.

Komolafe O. A., D. A. Ofusori, O. S. Adewole, A. A. Ayoka, and O. A. Ayannuga. 2013. Histomorphometric Studies Of The Aorta, Pulmonary Trunk And Left Ventricle Of Streptozotocin-Induced Diabetic Wistar Rats Treated With Momordica Charantia Extract. Diabetologia Croatica 42-1, 2013

Lu H. and Tan., 2009. A Comparative study of storage stability in virgin coconut oil and extra virgin Olive oil upon thermal treatment. International Food Research Journal 16: 343-354 (2009)

Liau, K.M.,1 Yeong Yeh Lee, Chee Keong Chen,and Aida Hanum G. Rasool, An Open-Label., Pilot Study to Assess the Efficacy and Safety of Virgin Coconut Oil in Reducing Visceral Adiposity, ISRN
Pharmacology, Volume 2011, Article ID 949686, 7 pages doi:10.5402/2011/949686

Marina A.M., Y.B. Che Mana, and I. Amin. 2009. Virgin Coconut Oil Emerging Functional Food Oil. Food Science \& Technology 20 (2009) 481-487

McGilvery R.W. dan G.W. Goldstein, 1996. Biokimia: Suatu Pendekatan Fungsional, Airlangga University Press.

Nevin K.G and T. Rajamohan. 2006. Virgin coconut oil supplemented diet increases the antioxidant status in rats. Food Chemistry 99 (2006) 260-266.

Nevin K.G and T. Rajamohan. 2007. Influence of virgin coconut oil on blood coagulation factors, lipid levels and LDL oxidation in cholesterol fed SpragueeDawley rats. eJournal of Clinical Nutrition and Metabolism, 2007 European Society for Clinical Nutrition and Metabolism. Published by Elsevier Ltd. All doi:10.1016/j.eclnm.2007.09.

Permana R, F. Rizqi, A. Pradana, I Dewa A. Susilawati, and T. Ermawati. 2013. Histomorphometrical Analysis of Coronary Atherosclerosis Lesions Formation in Rat (Rattus norvegicus) Model. Journal of Dentistry Indonesia 2013, Vol. 20, No. 3, 73-77

Saleh N.K and H. A Saleh. 2011. Olive Oil effectively mitigates ovariectomy-induced osteoporosis in rats. BMC Complementary and Alternative Medicine 2011, 11:10 doi:10.1186/1472-6882-11-10. http://www.biomedcentral.com/1472$\underline{6882 / 11 / 10}$

Skeaff C.M dan J. Mann. 2014. Ilmu Gizi. Editor Jim Mann dan A. Stewart Truswell. Alih Bahasa Andry Hartono. Penerbit EGC. Indonesia.

Yuniwarti E.Y.W, W. Asmara, W.T. Artama, and C.R. Tabbu, 2013. Virgin Coconut Oil Meningkatkan Aktivitas Fagositosis Makrofag Pascavaksinasi Flu Burung. Jurnal Veteriner Vol 14 No 2 Juni 2013 